\title{
TUBERCULOUS RHEUMATISM REPORT OF A CASE
}

BY

\author{
P. G. DALGLEISH \\ From the Department of Medicine, University of Bristol
}

(RECEIVED FOR PUBLICATION MAY 23, 1952)

Poncet (1897) first drew attention to the polyarthritis that sometimes accompanies tuberculosis, and the condition was described more fully by Poncet and Mailland (1903) and Poncet and Leriche (1909). In France and Germany reports of such cases have frequently been made, but in Great Britain they are uncommon and consequently the following case is thought worthy of record.

\section{Case Report}

History.-The patient, a girl aged 17, first seen as an out-patient in November, 1950, was complaining of pain, stiffness, and swelling of 2 months' duration in her knees, ankles, and fingers. There had also been vague pains in her shoulders and hips. She had been quite well until June, 1950, when she developed some lumbar backache, which was worse in the mornings, but wore off during the day. She had lost $11 \mathrm{lb}$. in the last 6 months. An $x$ ray of her chest, taken during the summer on account of an unproductive cough, showed no definite abnormality. There was no family history of tuberculosis. One year previously a moderately inflamed retrocaecal appendix had been removed because of recurrent pain in the right iliac fossa, anorexia, and vomiting. There was a small amount of fluid in the peritoneal cavity at that time, but no enlarged abdominal lymph glands were noted.

Examination.-The patient looked ill. There was swelling of all the interphalangeal joints of both hands and also of the right wrist. Movements of the right elbow and the knees were limited. Both ankle joints were slightly swollen, but no other abnormality was found on examination.

Laboratory Findings.-Erythrocyte sedimentation rate $53 \mathrm{~mm}$./hr (Wintrobe). Haematocrit (packed cell volume) 47 per cent. White cell count 6,000 per c.mm. with a normal distribution.

Electrocardiogram normal.

Radiographs of knees and elbows normal, but those of the hands (see Fig. 1) showed some soft tissue swelling around the interphalangeal joints.

Treatment.-She was admitted to hospital a few days later on December 1, 1950, with a diagnosis of rheumatoid arthritis. Her general condition improved with bed rest and the erythrocyte sedimentation rate settled to
$7 \mathrm{~mm} . / \mathrm{hr}$ by the middle of December. She was given "Myocrisin" in doses of $0.01 \mathrm{~g}$. twice weekly for the next 4 weeks.

Progress.-At the end of the third week she complained of pain in the right hip and thigh. There was severe and painful limitation of movement of this joint and $N$ tenderness over the greater trochanter. A radiographo of the right hip joint showed considerable osteoporosis

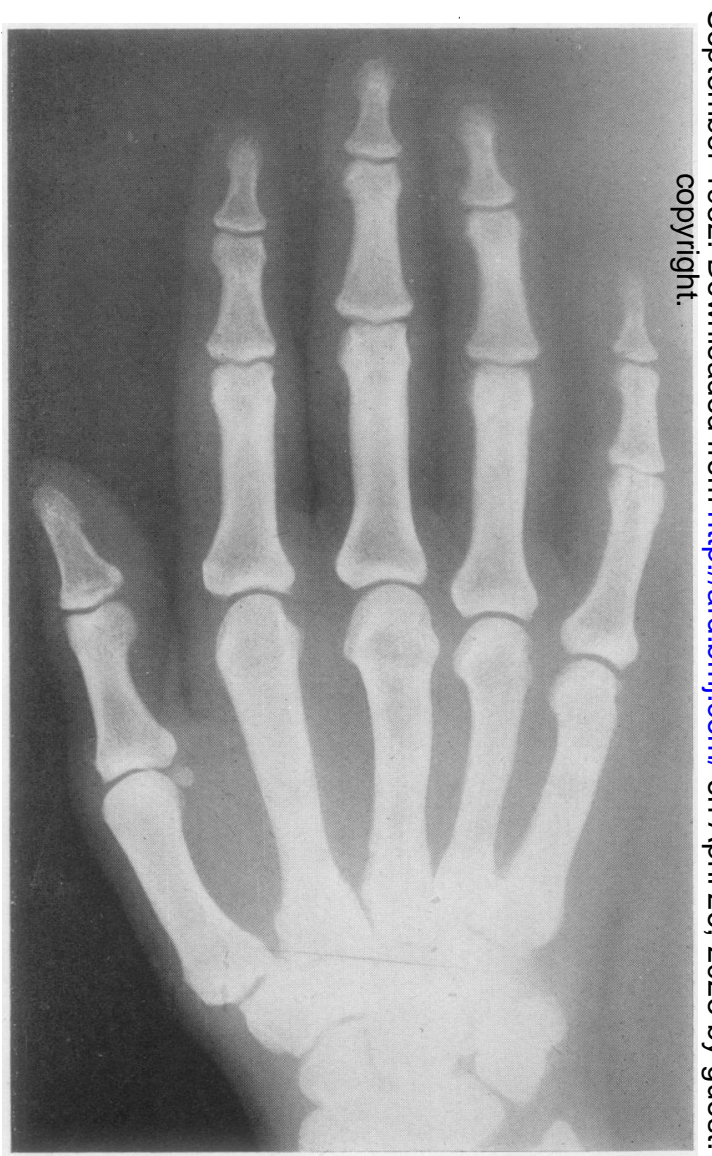

Fig. 1.-Radiograph of hand showing only soft tissue interphalangeal joints. November, 1950. 


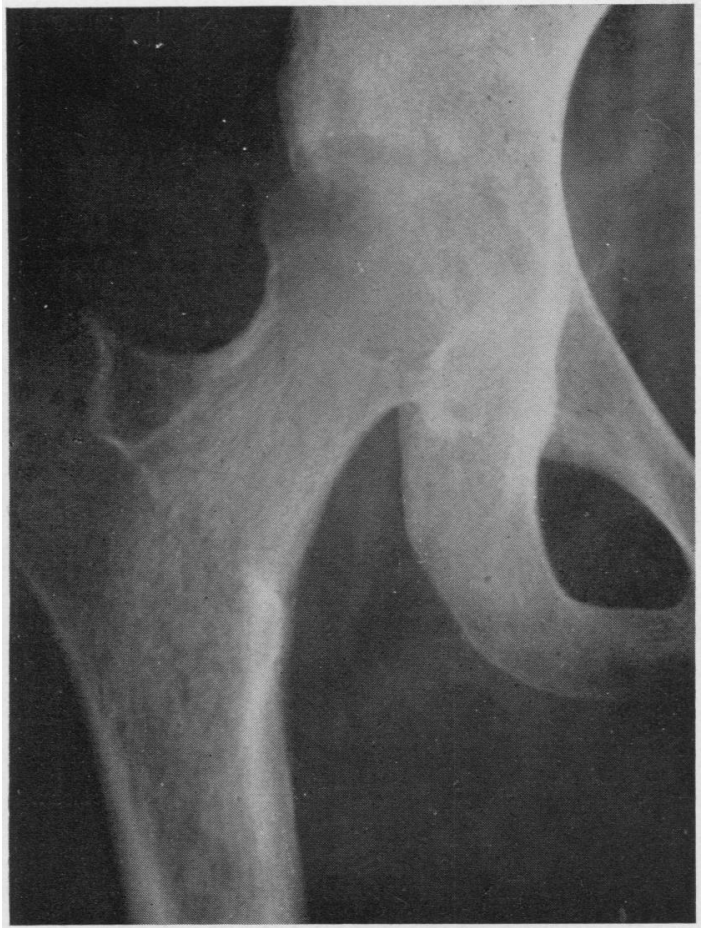

Fig. 2(a). Radiograph of right hip (February, 1951), showing destruction of joint space and articular cartilage. Osteoporosis and periostitis are present.

of the head of the right femur and of the acetabulum but no reduction of joint space. These changes were suggestive of tuberculous disease of the hip but this possibility was at the time thought to be unlikely and treatment of the polyarthritis was continued. Within a few days she began to run a low fever $\left(99^{\circ}-100^{\circ} \mathrm{F}\right.$.) with tachycardia which lasted about a week. A further blood examination showed that the haemoglobin, white cell count, and erythrocyte sedimentation rate were normal. The signs persisted in the right hip joint and subsequent $x$ rays showed increasing osteoporosis and destruction of part of the acetabulum.

In the middle of January, 1951, the diagnosis of tuberculous disease of the hip was accepted and traction was applied to the right leg. A radiograph of the chest showed no abnormality. At this time the Mantoux reaction was positive at 1 in 1,000 .

Further Treatment.-At the end of the month she was transferred to an orthopaedic hospital for further treatment of tuberculous disease of the right hip, by which time the polyarthritis had settled down, except for slight painless swelling of the interphalangeal joints of the fingers. She received streptomycin $(1.0 \mathrm{~g}$. daily) and para-amino salicylic acid ( $15 \mathrm{~g}$. daily) for 3 months from February to May, 1951. Traction was maintained on the right leg till September, 1951.

Later Progress.-During these months her condition slowly improved. The erythrocyte sedimentation rate

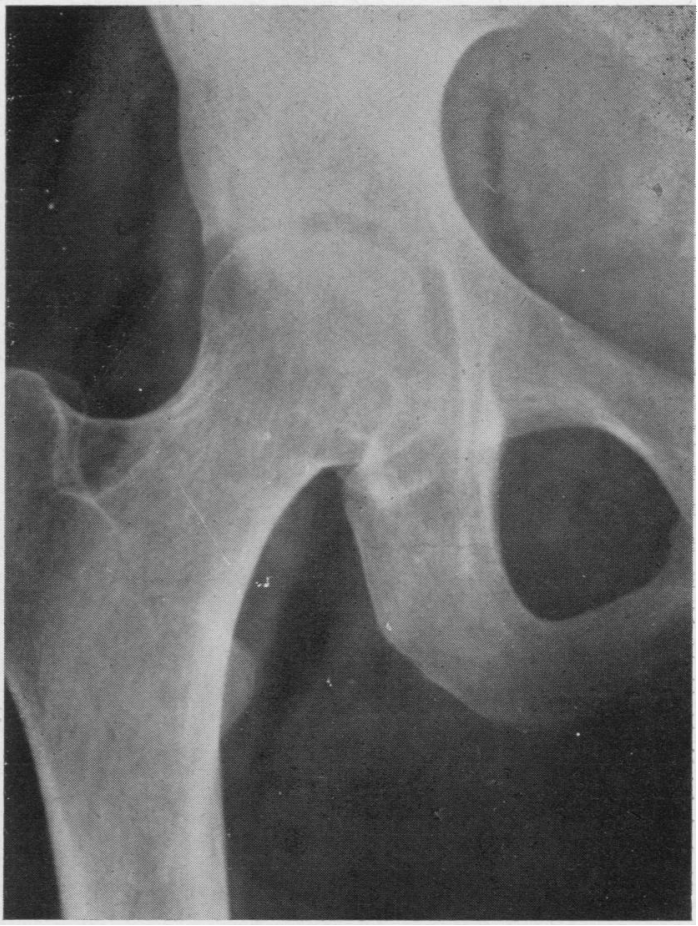

Fig. 2(b).-Radiograph of right hip (November, 1951). Recalcification of femur has occurred, and the joint space is partially reconstituted.

rose during February, 1951, to $90 \mathrm{~mm}$./ hr (Westergren), but had gradually returned to normal by September, 1951. Serial radiographs (see Fig. 2) showed progressive osteoporosis of the femoral head and destruction of cartilage and bone followed by recalcification and partial reconstitution of the joint. In November, 1951, she began to get up and she was discharged home in January, 1952. By that time the range of movement in the right hip had returned to two-thirds of normal and there were no signs of rheumatoid arthritis in the other joints.

\section{Discussion}

There seems to be little doubt that the disease in the right hip was tuberculous. Although this was not proved by biopsy or aspiration, the changes on serial $x$ rays, the clinical course, and the response to treatment were very suggestive of a tuberculous aetiology. Unfortunately no primary focus of tuberculosis was found. A septic arthritis would seem to be unlikely because of the protracted course of the disease and the normal white blood counts. The appearance and clinical course of the other joints were different and were indistinguishable from those of rheumatoid arthritis.

There are two possible theories for the production of the polyarthritis which accompanies tuberculosis. The first is that there is a mild tuberculous 
bacteraemia due to liberation of bacilli from some focus and that the organisms are not virulent enough to produce more than a non-specific inflammation in the joints. The second is that the polyarthritis is a sensitization phenomenon of the body to the tubercle bacillus. Both these possibilities have been considered by Brav and Hench (1934) in their critical review of the literature on the subject. Copeman (1936) reported twelve cases of rheumatoid arthritis with an associated tuberculous factor, in eleven of which a positive blood culture for tubercle bacilli was obtained for him by Professor Loewenstein. Nevertheless, Copeman considered that both the above theories might account for tuberculous rheumatism, while favouring one in which there was both a tuberculous bacteraemia and a sensitization of the joint surfaces. Because the tuberculous lesion was of a minor character in his patients he felt that their natural resistance was high and thus the tubercle bacilli were rapidly destroyed in the tissues and did not produce a true tuberculous polyarthritis but only a non-specific inflammation. Sheldon (1946) favoured the second theory when he reported this condition in six children. Coburn (1940) thought that the second theory might account for this phenomenon in tuberculosis and also in syphilis, and he likened it to the relationship of the haemolytic streptococcus to acute rheumatism. He suggested that patients suffering from acute rheumatism reacted abnormally to streptococcal infections, there being a delayed and abnormally protracted production of antibody by the cells of the reticulo-endothelial system, so that these cells became sensitized, an inflammatory reaction resulting when they came into contact with fresh antigen.

The theory of tuberculous bacteraemia is hard to substantiate as a cause of the polyarthritis because of the difficulty in recovering tubercle bacilli from the blood stream. The theory of sensitization to derivatives of the tubercle bacillus is more attractive, for this mechanism probably explains other manifestations such as erythema nodosum and those cases of purpura which accompany tuberculosis
(Dalgleish and Ansell, 1950).

\section{Summary}

The case is reported of a girl aged 17 who presentect with an acute rheumatoid type of polyarthritis.

This condition subsided but was followed in about 6 weeks by hip disease having all the featurese of a tuberculous arthritis.

The cause of the polyarthritis is thought to have been a sensitization phenomenon to the tubercle ${ }^{\infty}$ bacillus.

I should like to thank Professor Bruce Perry and Mr. H. K. Lucas for permission to report this case and for their helpful criticism, and Mr. F. A. Godman fo巴 the photographs.

\section{REFERENCES}

Brav, E. A., and Hench, P. S. (1934). J. Bone Jit Surg, 16, 839 i Coburn, A. F. (1940). Trans. Stud. Coll. Phys. Philad., 4 ser.j 8, 91.

Copeman, W. S. C. (1936). Rep. chron. Rheum. Dis., 2, $24 . \quad N$ Dalgleish, P. (i., and Ansell, B. M. (1950). Brit. med.'J., 1, 225. O
Poncet, A. (1897). Address to the Congrès français de Chirurgie See Bull. Acad. Méd., Paris, (1901), 46, 194.

- and Leriche, R. (1909). "Le rhumatisme tuberculeux." Doin, Paris.

and Mailland, M. (1903). “Rhumatisme tuberculeux. " Oeuvre méd.-chir., No. 34. Masson, Paris.

Sheldon, W. (1946). Lancet, 1, 119.

\section{Rhumatisme tuberculeux Rapport d'un cas}

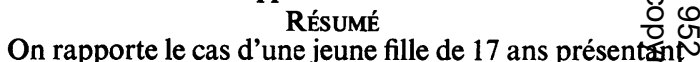
une polyarthrite du type rhumatismal aigu.

Cette affection s'améliora, mais six semaines plus to on observa l'atteinte d'une hanche portant tous les caractères d'une arthrite tuberculeuse.

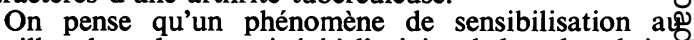
bacille tuberculeux aurait été à l'origine de la polyarthriteळ

\section{Reumatismo tuberculoso Relato de un caso Sumario}

Se relata el caso de una joven de 17 años presentand una poliartritis del tipo reumático agudo.

Esta afección retrocedió, pero seis semanas más tardè se vió todos los carácteres de una artritis tuberculos $₫$ coxo-femoral.

Se cree que un fenómeno de sensibilización al bacilở. tuberculoso podría haber causado la poliartritis. 